\title{
The Influence Factors to Academic Performance of Architecture Students in Malaysia
}

\author{
Azman Hasan, Jamil Abd Baser, Rasid Abd Razzaq, Saifullizam Puteh, Norzehan Ibrahim \\ University of Tun Hussein Onn Malaysia, \\ Johor, Malaysia
}

\begin{abstract}
The aim of this study was to identify students' academic performance degradation issues and also identify factors that affect the academic performance of the architecture students in Malaysia. The study is conducted through a qualitative research approach based on previous literature review. The previous study showed issues on the decreased of academic performance of architecture students in Malaysia whereby a lot of architecture students have difficulty in completing their studio tasks assigned by their lecturers. Besides that, the study found internal and external factors involving emotions will lead to a situation in which students 'stuck' and blank. Furthermore, the factors that affect the academic performance of the architecture students in Malaysia are student's inadequate sleep and irregular sleep schedule. The architecture students are also prone to problems related to numbness in areas of their hand due to awkward positions while doing their work. Lastly, the architecture students tend to face their PC or laptop screen working on assignments or projects until midnight skipping dinner or other responsibilities. This negligent practice may negatively affect their academic performance.
\end{abstract}

Keywords--Architecture Students, Academic Performance, studio tasks assigned

\section{INTRODUCTION}

\section{A. Architecture}

According to Rasdi et al. (2008), architecture is one of the field consists of Science, History of Architecture, Geography, Culture, Economics, Arts and also management. Ahmad et al. (2014) stated that architecture is all about the physical factors or elements which combined the elements of art and science. The architecture consists of three basic human needs which include the protective elements, artistic and symbolic and also the economy. In addition, the architecture provides a distinctive meaning to humans because it reflects the culture of each of the individuals and groups of the community. Through the prosperity of the people, the architecture can be sustained. (Ahmad et al., 2014).

\section{B. Architecture Education In Malaysia}

Architecture program in Malaysia is growing rapidly and many universities or institutions of Higher Education either the public or private education are offering an Architecture program that has been recognized by the Board of Architects Malaysia (LAM). (LAM, 2017). Up to now, there are seven universities offering the architecture program. Six of them have been fully accredited by LAM. Among them are the Universiti Teknologi Malaysia (UTM), Universiti Teknologi MARA (UiTM), Universiti Sains Malaysia (USM), Universiti Malaya (UM), International Islamic University Malaysia (IIUM), and Universiti Putra Malaysia (UPM). However, the last of the seven, Universiti Kebangsaan Malaysia (UKM) is still in the evaluation stage. (LAM, 2017).

Apart from the architecture program that has been recognized by the LAM Part I and II, there are also other educational institutions that offer architecture programs in the Diploma of Architecture. The institutions are Ungku Omar Polytechnic (PUO), Port Dickson Polytechnic (PPD), Sultan Ahmad Shah Polytechnic (POLISAS), Merlimau Polytechnic and Sultan Abdul Halim Polytechnic (POLIMAS). (Hala Tuju Pendidikan Seni Bina, 2014).

Furthermore, there are also private institutions recognized by LAM which is Taylor's University, UCSI University Kuala Lumpur, Kuala Lumpur Infrastructure University (IUKL), Universiti Tunku Abdul Rahman (UTAR), Limkokwing Executive Leadership College (LELC) and Limkokwing University of Creative Technology (LUCT). (LAM, 2017). For those who want to become an architect as their profession after graduating, they have to further pursue a special course offered by the architecture program. One should pass a Bachelor of Architecture and Master of Architecture (Part II) from their previous university. They also have to pass the examination conducted by the Board of Architects Malaysia and the Malaysian Institute of Architects (Part III) for recognition as a qualified architect. (LAM, 2017).

\section{Student's Academic Performance}

Academic achievement is very important for students at the university level. Ghafar and Weng (2002) state that at the tertiary level, the academic performance of a student is very important in determining the degree classes that they will obtain upon complete their studies. If a student fails, it will, unfortunately, threaten their future. Typically, the academic excellence of the students is determined by students performance in their examination. A study conducted by Johan and Majid (2008) says that in general, academic achievement determines the level of achievement of each individual in a formal and public examination taken by the Ministry of Education.

However, each student will show a different level of academic achievement. According to Abdul Muqsith Ahmad (2013), he states that the level of educational achievement for every person is different from each other and this difference is 
caused by various factors that influence it. Mucowski (1984) in his study proves that there are six main factors that obstruct the learning process of an individual. The factors are unsatisfactory academic performance, social disruption and interpersonal, family crisis, financial problems, mix-up goals and conditions that are being experienced as a health problem.

Previous studies showed that the academic performance of the art related subject such as visual art and technical drawing is unsatisfactory. Based on research done by Ismail (2015), the Performance Report of Sijil Pelajaran Malaysia (SPM) 2013 for Visual Arts Education subject in Malaysia indicates that $60 \%$ of students got an average and low marks. This indicates that there are still many poor students who unable to master the subject. The researchers described the level of spatial visualization of his students are very low, although there can also be due to the various factors that influence the result.

In addition, previous studies reported that students often have difficulty in translating their drawings in the technical drawing subject. (Saud and Lee, 2007). The results of the Sijil Pelajaran Malaysia (SPM) from 2004 to 2009 in this subject showed poor performance further supports the study. Academic achievement is crucial and must be taken seriously by students. According to the researchers Ghafar and Weng (2002), academic achievement is very important because the consequences of failure could threaten their future. Among others, researcher Iberahim (2014) found that when the activities in the classroom were unable to be conveyed clearly, the sense of interest and concentration of the students on the lesson will plummet. This statement is supported by Bakar (1988) whereby according to him, interests and fondness play a very important role in influencing students learning capability. Someone who is interested in what they studied resulted in high achievement and same goes otherwise.

In the context of architecture students, they must have the ability to empower them to produce a very responsive, excellence and sensible product of architecture according to the requirements of the environmental, social and economic. According to Ahmad et al. (2014), the quality and ability of a person who holds the title architect's basically taken shape during the stage of formal learning. This also determines the extent to which they can survive in this profession. The effect and impact of the difficult learning can lead to failure in academic achievement (Iberahim, 2014).

Architect profession is often described as a prestigious profession, elite, prosperous and highly skilled. However, the architecture education is not as easy as we thought. (Rasdi et al. 2008). There are several factors that effect and the problems they will face that will ultimately affect their academic performance. In this research, the author intends to identify students' academic performance degradation issues and also identify factors that affect the academic performance of architecture students in Malaysia. Therefore, a study to identify the situation happening among university students majoring in architecture are needed to find out whether or not the situation is the similar with the researchers mentioned previously.

The aim of this study was to identify students' academic performance degradation issues and also identify factors that affect the academic performance of the architecture students in
Malaysia. This study is to be used by academics, teachers and students who focus primarily on architecture as a career. This review is said to be done to find out the real situation happens to the architecture students in universities in Malaysia.

The research question of this study will be divided into several sections: (1) Is there an issue regarding the decreased of academic performance of architecture students in Malaysia? (2) What are the factors that affect the academic performance of architecture students in Malaysia?

\section{METHOD}

This study was conducted through a qualitative research approach based on previous literature review. A previous study has been used in order to get a precise answer to research questions.

\section{RESULT AND DISCUSSION}

Based on the first research question, Sachs (1999) stated that only a few architecture students can complete the studio tasks without having difficulty and dilemma. This proves that normally students will have difficulty in completing their tasks assigned by the lecturers. This difficulty could reduce their academic performance ultimately will affect the grades and scores given later. In addition, the study found that the internal and external factors will lead to a situation in which students 'stuck' and blank. (Sachs, 1999). Because of this, it will indirectly affect the progress of their final project. When they stuck, they will not be able to produce a quality product at the end of the day. The results will lead to the lower grades and marks.

In a study conducted by Oluwatayo et al. (2015), they found that the perception of schedule inflexibility, positive assessment and equal treatment affect the overall grade of the architecture students. The researcher Demirbaș (2001) stated that through their observation, students of architecture that have a positive perception of their learning and learning environment will tend to do best in producing high-quality work.

Based on the second research question, kentwired.com website states that architecture students need to work longer and had to sacrifice their sleeping time. (Graff, 2014). Most of the college students make every effort to maintain an adequate sleep schedule and architecture students at Kent State University complained that they had to stay up all night to ensure their work is completed. According to the author, they are still at the studio M.A.C Annex between 2 am until 4 am to complete their respective tasks. Studies show that sleep schedules that are irregular and inadequate sleep can lead to negative consequences in a person's health. It can compromise the student's concentration during class and will contribute to a lower academic performance.

In addition, the architecture students are also prone to have problems related to numbness in areas of their hand when they are in an awkward position while doing their work. Dogru et al. (2015) showed that fourth-grade students of the architecture 
program at Mustafa Kemal University, Faculty of Architecture, Hatay, Turkey spent more hours than the first-grade students drawing in a day. Later, the fourth-grade student's complaint having a tingling-needing and numb in firstly their fingers, later the numbness spread to the forearm. At the end, it was proved counterproductive as it leads to difficulties in the drawing. Moreover, this problem also leads to sleeping difficulties which resulted in students end up not getting enough sleep. This compromises their attention in class.

In a study conducted by Azmi et al. (2002) stated that the presence of computer technology has brought changes to human behaviour. In a bold statement, he stated human had become slaves to the computer. People sit in front of a computer for hours until late at night, neglecting their responsibilities to family and also responsibility towards their own self. In relation to architecture students, they tend to face their PC or laptop screen working on assignments or projects until midnight skipping dinner or other responsibilities. This is proved by lifeofanarchitecturestudent.net website where one of architecture students shared her experience of working on an assignment, she skipped dinner and finally, she just drank coffee only. This practice may negatively affect her academic performance. As support, the study done by Philip (2005) found that students who eat breakfast have a higher success rate in Biology examinations rather than who do not take their breakfast.

\section{CONCLUSION}

In conclusion, it clearly shows that there is the issue of decreasing academic performance of architecture students. With the evidence explained by previous researchers, an architecture program is indeed a challenging degree. There are external factors that contributed to the deterioration of a student's academic performance. In order to improve the academic excellence of the architecture students, studies alike are needed to identify the real situation happening among architecture students at the university in Malaysia. The study was conducted for the purpose of being used by academics, teachers and students who focus primarily on architecture as a career. Therefore, a study to identify the situation and the phenomenon of architecture students in the university are needed.

\section{REFERENCE}

[1] Ahmad, A. M. (2013). Faktor Yang Mempengaruhi Perbezaan Pencapaian Akademik Pelajar Lepasan Diploma Politeknik Dan Matrikulasi Terhadap Subjek Kejuruteraan. Fakulti Pendidikan Teknikal dan Vokasional Universiti Tun Hussein Onn Malaysia. UTHM

[2] Ahmad, A. S. H., Rahman, A. M. A., Nawawi, N. M., Ibrahim, N., Razali, M. M. F. M., Surat, M., \& Yaacob, N. M., (2014). Halatuju Pendidikan Senibina di Malaysia. Terbitan Universiti Putra Malaysia,
UPM, Serdang. Dicapai pada 5 Mei 2017, dari http://www.moe.gov.my/images/Terbitan/RujukanAkademik/Hala\%20Tuju\%20

Pendidikan\%20Seni\%20Bina\%20di\%20Malaysia.pdf

[3] Azmi H., Mohd Kamil H., W. Fadhilah W.H. (2002), Tekanan Kerja dan Masalah Kesihatan di Kalangan Pengguna-Pengguna Komputer di Pejabat Kesihatan Negeri Terengganu. Malaysian Journal of Public Health Medicine 2002, Vol. 2(1):13-20

[4] Bakar, A. Z. A. (1988). Memahami Psikologi Pembelajaran, Petaling Jaya: Penerbit Fajar Bakti.

[5] Demirbaş, O. O. (2001). The Relation of Learning Styles and Performance Scores of the Students in Interior Architecture Education. Retrieved from http://www.thesis. bilkent.edu.tr/0001800.pdf

[6] Dogru, E., Kizilci, M. H., Duman, F., Korkmaz, N.C., Canbay, O., Yucekaya, B. (2015). Researching Effects of Drawing on Prevalence of Carpal Tunnel Syndrome with Architecture Students. Science Journal of Public Health. Vol. 3, No. 2, 2015, pp. 237-241. doi: 10.11648/j.sjph.20150302.22

[7] Ghafar, M. N. A. \& Weng, Y. C. (2002). Perkaitan Antara Pengurusan Masa Dengan Pencapalan Akademik Pelajar Utm. Fakulti Pendidikan Universiti Teknologi Malaysia. Jurnal Pendidikan Universiti Teknologi Malaysia. Jilid 8 Oktober 2002. hal. 71-92.

[8] Graff, C. (2014). Kentwired. Architecture Students Suffer From Sleep Deprivation, Study Says. Dicapai pada 12 Mei 2017 dari http://www.kentwired.com/latest_updates/ article_23fc889e-790e-11e483c2-13c76fe91d21.html

[9] Iberahim, H. (2014), Pengaruh Faktor Persekitaran Terhadap Kecemerlangan Akademik Pelajar Fakulti Kejuruteraan Mekanikal dan Pembuatan Serta Pelajar Fakulti Kejuruteraan Elektrik di UTHM, Universiti Tun Hussein Onn Malaysia.

[10] Ismail, F. (2015). Kemahiran Menvisualisasi Ruang Dalam Kalangan Pelajar Bagi Mata Pelajaran Pendidikan Seni Visual. Fakulti Pendidikan Teknikal dan Vokasional Universiti Tun Hussein Onn Malaysia. UTHM

[11] Johan, O. B. M., \& Majid, R. B. A., (2008). Faktor-Faktor Yang Mempengaruhi Pencapaian Akademik Pelajar Tahun 4 Perdana, Jabatan Pendidikan Teknikal Dan Kejuruteraan, Sesi 2007/2008, Fakulti Pendidikan UTM, Skudai Fakulti Pendidikan, Universiti Teknologi Malaysia.

[12] LAM. (2017). Senarai Program Seni Bina Yang Diiktiraf. Dicapai pada 10 Mei 2017 dari http://www.lam.gov.my/accreditation/list-ofrecognised-programmes

[13] Mucowski, Richard. (1984). Some common problems of new students and sources of help. Journal of College Student Personnel (November): 550-551.

[14] Oluwatayo, A.A, Aderonmu, P.A \& Aduwo, E. B. (2015). Architecture Students' Perceptions of Their Learning Environment and Their Academic Performance. Learning Environ Res (2015) 18:129-142 DOI $10.1007 / \mathrm{s} 10984-015-9172-7$

[15] Phillips, G. W. (2005). Does Eating Breakfast Affect the Performance of College Students on Biology Exams? Bioscene: Journal of College Biology Teaching, 30(4), 15-19.

[16] Rasdi, M. T. M., Ibrahim, F. K., Salleh, M. R., \& Isa, N. M (2008). Kerjaya bidang seni bina. Johor: Penerbit UTM Press.

[17] Sachs, A. (1999). 'Stuckness' in the design studio. Architecture Publications and Other Works. University of Tennessee, Knoxville

[18] Saud, M. S. \& Lee, M. F. (2007). Hubungan antara kognitif visual dengan pencapaian Lukisan Kejuruteraan di kalangan pelajar sekolah menengah teknik. Paper presented at 1st International Malaysian Educational Technology Convention, Sofitel Palm Resort Senai, Johor Bahru. 2-5 December. 